(๑) Group of authors, 2018

UDC 616.36-089+616.5-076

DOI https://doi.org/10.14300/mnnc.2018.13098

ISSN - 2073-8137

\title{
TRANSJUGULAR ADJUSTED LIVER BIOPSY
}

\author{
Khoronko Yu. V. ${ }^{1}$, Cherkasov M. F. ${ }^{1}$, Awerkiew S. ${ }^{2}$, Groshilin V. S. ${ }^{1}$, \\ Kivva A. N. 1, Kosovtsev E. V. 1, Chumburidze I. P. 1, Shamik V. B. ${ }^{1}$ \\ ${ }^{1}$ Rostov State Medical University, Rostov-on-Don, Russian Federation \\ 2 Cologne University, Uniclinic, Germany
}

\section{ТРАНСЪЮГУАЯРНАЯ ПРИЦЕАЬНАЯ БИОПСИЯ ПЕЧЕНИ}

\author{
Ю. В. Хоронько ', М. Ф. Черкасов ${ }^{1}$, С. Аверкиева ${ }^{2}$, В. С. Грошияин ${ }^{1}$, \\ А. Н. Кивва ${ }^{1}$, Е. В. Косовцев ${ }^{1}$, И. П. ЧумбуриАзе ${ }^{1}$, В. Б. Шамик ${ }^{1}$ \\ 1 Ростовский госуАарственный меАицинский университет, Ростов-на-Аону, \\ Российская Фелерация \\ 2 Кёльнский университет, Университетская к^иника, Германия
}

Twenty two patients with contraindications to percutaneous liver biopsy were underwent transjugular liver biopsy, because of requirement for histological assessment was continued. Transjugular approach and endovascular passing through hepatic veins allow achieving the zone of surgical interest and perform liver biopsy able to provide specimens of good quality with possibility of histological examination.

Keywords: liver biopsy, transjugular approach

Трансъюгулярная биопсия печени выполнена 22 больным, у которых выявлены противопоказания к проведению чрескожной биопсии, но сохранялась необходимость морфологической верификации патологического процесса. Особенности ангиоархитектоники печеночных вен позволяют прицельно проникнуть в зону диагностического интереса эндоваскулярным путем и получить качественный биопсийный материал.

Ключевые слова: биопсия печени, трансъюгулярный доступ

For citation: Khoronko Yu. V., Cherkasov M. F., Awerkiew S., Groshilin V. S., Kivva A. N., Kosovtsev E. V., Chumburidze I. P., Shamik V. B. TRANSJUGULAR ADJUSTED LIVER BIOPSY. Medical News of the North Caucasus. 2018;13(3):534-535. DOI - https://doi.org/10.14300/mnnc.2018.13098

Для цитирования: Хоронько Ю. В., Черкасов М. Ф., Аверкиева С., Грошилин В. С., Кивва А. Н., Косовцев Е. В., ЧумбУридзе И. П., Шамик В. Б. ТРАНСЪЮГУЛЯРНАЯ ПРИЦЕЛЬНАЯ БИОПСИЯ ПЕЧЕНИ. МедИЦИнСКИЙ веСтник Северного Кавказа. 2018;13(3):534-535. DOI - https://doi.org/10.14300/mnnc.2018.13098

HCC - Hepatocellular Carcinoma

HPVG - Hepatoportal Venous Gradient

TIPS - Transjugular Intrahepatic Portosystemic Shunt
TJALB - Transjugular Adjusted Liver Biopsy

PLB - Percutaneous Liver Biopsy
P ercutaneous liver biopsy (PLB) with ultrasound guidance is characterized as the most common procedure with important diagnostic potential in patients with liver diseases [1]. PLB is a procedure with low complication rate. But in patients with clinically demonstrable ascites, a known or suspected severe coagulopathy, platelet count of less than $50 \times 10^{9} / \mathrm{L}$ standard liver biopsy associated with high risk of life-threatening bleeding to abdominal cavity $[2,3]$. Transjugular approach and following biopsy via the hepatic veins reduces the risk of Glisson capsule's perforating and hemoperitoneum. Moreover, hepatic veins' angioarchitectonics allow to achieve a zone of surgical interest using endovascular approach and receive the tissue samples for diagnostic purposes $[4,5]$.
Aim of the study was to analyze retrospectively the results of transjugular adjusted liver biopsy (TJALB) and to compare our results with those presented in literature. Also we objective to estimate of possibility to perform TJALB of different liver segments for increase the efficiency of the procedure. TJALB is performed in an interventional radiology operation room with strictly aseptic rules, control of patient's vital signs and heart monitoring to detect arrhythmia during catheter passing through right atrial sinus.

Material and Methods. Twenty two patients underwent TJALB in our clinic in 2015-2018. All of these patients have contraindications for using routine PLB due to severe coagulopathy, thrombocytopenia and/or ascites. There were the following indications for TJALB: histological evaluation of the liver in patients with high 
risk of hepatocellular carcinoma (HCC) and assistance for make therapeutic decisions in chronic viral liver disease. In 4 patients TJALB was an independent procedure and in 18 patients with liver cirrhosis - as a phase of transjugular intrahepatic portosystemic shunt (TIPS). Our experience of TIPS creation is 230 patients with complicated cirrhotic portal hypertension operated on in 2007-2018, so we haven't any technical difficulties performing TJALB in 2015-2018. The semiautomatic system Quick-Core ${ }^{\circledR}$ Biopsy Needle, which allows to receive less fragmented samples were used in all cases

Results and Discussion. TJALB was technically successful in all $22(100 \%)$ patients. Seventy five samples were received (3.4 on an average from patient) with mean size of the specimen $11.6 \pm 3.8 \mathrm{~mm}$ and $90.1 \%$ of following histologic success. The mean number of portal triads (complete portal tracts) per core sample was $8.1 \pm 2.3$ (range 6-21). According to literature, specimens with more than 6 CPT are reflecting a good quality of procedure. Sample's fragmentation was noticed in $30 \%$. The difference between cases of liver tissue with and without cirrhosis was no noticed. The mean time of procedure 34.0 min (range 12-47). Histological assessment revealed HCC in 3 patients, colorectal metastases - in
1 and allowed to establish a stage of viral hepatitis in 17 patients, which provided an effective management. The post-biopsy transitory abdominal pain was only in one case among 4 patients, who underwent the independent procedure. Neck hematoma was noticed in 2 patients. There were no capsular perforations. Careful passes of biopsy needle not too close to the Glisson's capsule may prevent this complication. So, the overall complications' rate was $13.6 \%$ without major complications and death. Postoperative period for patients with combination of TJALB with TIPS was comparable with after TIPS procedure alone. There was no mortality. The measurement of hepatoportal venous gradient (HPVG) during TJALB procedure is possible by measuring of the wedge pressure and hepatic venous pressure. Result of HPVD is actual for treatment of portal hypertension.

Conclusions. TJALB is an effective diagnostic procedure for high-risk patients characterized by low morbidity and mortality. It allows performing liver biopsy if patient has any contraindications to standard PLB but requirement in histological assessment continued. TJALB is able to provide specimens of good quality with possibility of histological examination. It's necessary to emphasize that only an experienced interventional radiologist has to perform the TJALB procedure.

Disclosures:

The authors declare no conflict of interest.

References

1. Sparchez Z., Mocan T. Contemporary role of liver biopsy in hepatocellular carcinoma. World J. Hepatol. 2018;10(7):452-461. https://doi.org/10.4254/wjh.v10.i7.452

2. Collecchia A., Scaioli E., Montrone L., Vestito A., Di Biase A. R. [et al.] Preoperative liver biopsy in cirrhotic patients with early hepatocellular carcinoma represents a safe and accurate diagnostic tool for tumour grading assessment. J. Hepatol. 2011:54(2):300-305. https://10.1016/j.jhep.2010.06.037

3. Filingeri V., Sforza D., Tisone G. Complications and risk factors of a large series of percutaneous liver biopsies in patient with liver transplantation and liver disease. Eur. Rev. Med. Pharmacol. Sci. 2015;19(9):1621-1629.

4. Ble M., Procopet B., Miquel R., Hernandez-Gea V., Garcia-Pagan J. C. Transjugular liver biopsy. Clin. Liver Dis. 2014;18(4):767-778 https://doi.org/10.1016/j.cid.2014.07.001

5. Dohan A., Guerrache Y, Boudiaf M., Gavini J.-P, Kaci R. [et al.] Transjugular liver biopsy: Indications, technique and results. Diagn. Intervent. Imaging. 2014;95(1):11-15. https://doi.org/10.1016/diii.2013.08.009

\footnotetext{
About authors:

Khoronko Yury Vladilenovich, DMSc, Docent, Chief of Chair of Operative Surgery and Clinical Anatomy, surgeon of Department of Surgery; tel.: +79381000483; e-mail: khoronko507@gmail.com

Cherkasov Mikhail Fedorovich, DMSc, Professor, Chief of Chair of Surgical Diseases of FPK and PPS tel.: +79188923200; e-mail: cherkasov_mixail@mail.ru

Awerkiew Sabine, MD, Professor, Vice-Director Of Institute of Virology, Chief of Laboratory for Viral Ummunology; Uniclinic; tel.: +491714246753; email: sabine.awerkiew@uk-koeln.de

Groshilin Vitalii Sergeevich, DMSc, Docent, Chief of Chair of Surgical Diseases № 2;

tel.: +79185004229; e-mail: groshilin@yandex.ru

Kivva Andrey Nikolaevich, DMSc, Professor, Professor of Chair of Operative Surgery and Clinical Anatomy; tel.: +79185059591; e-mail: kiva@aaanet.ru

Kosovtsev Evgeniy Valeryevich, MD, Chief of Department of Roentgenosurgical Methods of Diagnostics and Treatment; tel.: +79043423302; e-mail: kosovtsev@yandex.ru

Chumburidze Igor Pavlovich, DMSc, Professor, Professor of Chair of Surgical Diseases № 3.

tel.: +79281624472, e-mail: ic58@mail.ru

Shamik Viktor Borisovich, DMSc, Professor, Professor of Chair of Surgical Diseases of FPK and PPS;

tel.: +79188923200
} 